\title{
Evaluation of the Prognostic Value of Preoperative Neutrophil-to- lymphocyte Ratio in Renal Cell Carcinoma
}

\section{Renal Hücreli Kanserlerde Preoperatif Nötrofil Lenfosit Oranının Prognostik Belirteç Olarak Değerlendirilmesi}

\author{
(D) İsmail Basmacı, (D) Serdar Çelik, (D) Ertuğrul Şefik, (D) Erhan Aydın, (D) Serkan Yarımoğlu, (D) İbrahim Halil Bozkurt, \\ (D) Tansu Değirmenci \\ Bozyaka Training and Research Hospital, Clinic of Urology, izmir, Turkiye
}

What's known on the subject? and What does the study add?

Neutrophil/lymphocyte ratio (NLR) has been investigated as a prognostic marker in many cancers. In this article we aimed to investigate the prognostic value of NLR in renal cell carcinoma.

\begin{abstract}
Objective: To investigate the prognostic value of neutrophil-to-lymphocyte ratio (NLR) in renal cell carcinoma (RCC).

Materials and Methods: Preoperative NLR value in 125 patients who underwent surgical treatment for renal tumor between January 2012 and September 2017 and and received the pathological diagnosis of RCC, was evaluated. The patients were initially divided into two groups as patients with and without metastases at the time of diagnosis.

Subsequently, the patients were divided into two groups according to the pathological stage. In the first group, patients with localized RCC (pT1 and pT2) were evaluated and in the other group, those with advanced RCC (pT3 and pT4) were evaluated, and then, these two groups were compared.

Results: The mean NLR was higher in group with metastasis than in group without metastasis at the time of diagnosis (4.4 \pm 2.8 and $2.9 \pm 1.6$, respectively; $p=0.029$ ). When a NLR of 3.1 was taken as the cut-off value; it was observed that the NRL value in 7 of 8 patients with metastasis at diagnosis was above 3.1. ( $p=0.002, O R=14.6)$. Overall survival was $59.8 \pm 2.7$ months and $49 \pm 4.5$ months in patients with a NLR of $<3.1$ and $>3.1$, respectively $(p=0.045)$.
\end{abstract}

Conclusion: We assume that preoperative NLR can be evaluated as a prognostic marker for overall survival in patients with RCC.

Keywords: Renal cell carcinoma, Neutrophil-to-lymphocyteratio, Prognostic marker

Öz

Amaç: Renal hücreli kanserlerde (RHK) prognostik belirteç olarak nötrofil lenfosit oranının (NLO) etkinliğini araştırmak.

Gereç ve Yöntem: Ocak 2012 - Eylül 2017 tarihleri arasında böbrek tümörü nedeniyle cerrahi tedavi uygulanan ve RHK patolojisi olan 125 hastanın preoperatif NLO'su değerlendirildi. Hastalar ilk tanı anında metastaz olanlar ve olmayanlar olarak iki gruba ayrıldı. Ardından hastalar patolojik T evresine göre iki gruba ayrıldı. İlk grupta T1 ve T2 evreli lokalize hastalar, diğer grupta T3 ve T4 evreli invaziv hastalar değerlendirilerek veriler bu iki grup arasında karşılaştırılarak incelendi.

Bulgular: NLO tanı anında metastazı olan grupta, metastazı olmayan gruba oranla daha yüksekti (sırasıyla $4,4 \pm 2,8$ ve $2,9 \pm 1,6 ; p=0,029$ ). NLO=3,1 değeri sınır değer olarak alındığında tanı anında metastatik olan 8 hastanın 7'sinin değeri 3,1'in üzerinde olduğu gözlendi ( $p=0,002,0 R=14,6)$. NLO $<3,1$ olan hastalarda genel sağkalım 59,8 2,7 ay iken NLO $>3,1$ olan hastalarda $49 \pm 4,5$ ay olarak saptandı $(p=0,045)$.

Sonuç: Bu çalışmada preoperatif NLO, RHK hastalarında genel sağkalım açısından prognostik belirteç olarak değerlendirilebileceği gösterilmiştir. Anahtar Kelimeler: Renal hücreli kanser, Nötrofil lenfosit oranı, Prognostik belirteç

Correspondence: İsmail Basmacı MD, Bozyaka Training and Research Hospital, Clinic of Urology, İzmir, Turkiye

E-mail: ibasmaci@yahoo.com ORCID-ID: orcid.org/0000-0001-5012-6590

Received: 17.07.2018 Accepted: 12.12.2018

Cite this article as: Basmacı I, Çelik S, Şefik E, Aydın E, Yarımoğlu S, Bozkurt ï, Değirmenci T. Evaluation of The Prognostic Value of Preoperative Neutrophilto-lymphocyte Ratio in Renal Cell Carcinoma. J Urol Surg 2019;6(3):218-224.

๑Copyright 2019 by the Association of Urological Surgery / Journal of Urological Surgery published by Galenos Publishing House. 


\section{Introduction}

Renal cell carcinoma (RCC) represents 2-3\% of all cancers, and is the most common genitourinary malignancy after prostate and bladder cancer (1). As a result of the increased widespread use of computed tomography (CT) and ultrasonography (USG), the frequency of incidental identification of early stage tumors has increased $(2,3)$. Nearly $8 \%$ of patients with localized disease, who undergo partial or radical nephrectomy, develop metastatic disease during follow-up (4). A variety of models based on clinicopathological findings, such as TNM stage and Fuhrmann nuclear grade have been developed to estimate the outcomes for RCC patients to determine postoperative risks and to develop individualized treatments $(5,6)$. Other well-known prognostic factors are lymphocyte infiltration and histological subtype. However, not all of these prognostic factors are reliable (7). In clinical practice, a prognostic factor will have a great potential if it is easily evaluated, cheap and can be used in routine practice.

Many studies have shown the role of local and systemic inflammation in the development of cancer metastasis (8). Due to this effect, neutrophil-to-lymphocyte ratio (NLR) has been assessed as an independent prognostic factor for inflammation and many cancer types (9). A high NLR has been defined as a prognostic factor for poor overall survival, disease-free survival and progression-free survival in cancer patients (9). Our aim in this study was to assess the prognostic value of preoperative NLR in predicting survival and tumor recurrence in RCC patients.

\section{Materials and Methods}

Records of 153 patients, who underwent surgical treatment due to kidney tumors at our clinic from January 2012 to September 2017, were retrospectively analyzed in accordance with the ethical principles of the Helsinki Declaration. Twenty-eight patients, including 10 with benign results, 8 with urothelial carcinoma, 1 with lymphoma and 9 with missing data, were excluded from the study. The remaining 125 patients were included in the study.

Demographic data (age and sex), preoperative radiological findings (presence of invasion and metastasis at the time of diagnosis), preoperative laboratory data (serum neutrophil and lymphocyte levels and neutrophil/lymphocyte ratio), operation data, operation side, pathologic data (pathologic T stage, tumor size, Fuhrmann nuclear grade, tumor histology) and postoperative follow-up data (follow-up imaging) were investigated. All patients were assessed preoperatively with thoracic, abdominal and pelvic CT. According to the pathologic T stage determined by the 2010 TNM classification system, cellular evaluation was made using the Fuhrmann grading system $(10,11)$. Preoperative full blood count was evaluated 1 day before the operation with no blood transfusion, no active infection or fever. Preoperative NLR was calculated by dividing neutrophil count by lymphocyte count.

For patient follow-up, the kidney tumor follow-up protocol stated in the EAU 2010 guidelines was used (12). Accordingly, low-risk patients ( $\mathrm{pT} 1 \mathrm{a}, \mathrm{pT} 1 \mathrm{~b})$ underwent USG and chest X-ray once every 6 months in the first postoperative year and once a year after that. Intermediate-risk patients had thoracic and abdominal CT at 6 months, 2 and 5 years postoperatively and annual USG and chest $x$-ray at 1, 3, 4 and 5 years postoperatively. High-risk patients underwent thoracic and abdominal CT every 6 months in the first year and every year afterwards. Mortality data for patients were obtained from the Turkish Statistical Institute database and the hospital database. The patients were last assessed in October 2017. Overall survival was calculated as the duration in months from the date of operation until death due to any cause. Presence of metastasis at the time of diagnosis was identified with preoperative radiological investigation and patients with metastasis after surgical treatment were referred to medical oncology. Patients without preoperative clinical metastasis were assessed according to radiological evaluation results for recurrence and metastasis presence during follow-up.

The patients were initially divided into two groups as those with and without metastasis according to the presence of clinical metastasis at the time of diagnosis. All data were compared between the groups. Then patients were further divided into two groups according to pathologic T stage. The first group included patients with $\mathrm{pT} 1$ and $\mathrm{pT} 2$ stage localized RCC and the other group pT3 and pT4 stage invasive RCC. The data in these two groups were compared and investigated.

\section{Statistical Analysis}

Continuous data from the demographic information of patients were analyzed descriptively, while categorical data were analyzed according to frequency and proportion. Firstly, patients with and without metastasis at the time of diagnosis were compared. Then, the pT1 and pT2 patients were compared with pT3 and pT4 patients. In the comparisons the Mann-Whitney U test, binary logistic regression analysis and Pearson's chi-square test were used. Survival analysis was done using the KaplanMeier method. All data were analyzed with the Statistical Package for Social Sciences, version 20.0 (SPSS, Chicago, III) software program. Data were given as mean \pm SD. A $p$ value of less than 0.05 was considered statistically significant.

\section{Results}

The data on demographic characterstics, preoperative radiological and clinical findings, pathological findings and follow-up data for the 125 patients [79 (63.2\%) male and 46 
(36.8\%) female] included in the study are shown in Table 1. The median follow-up duration was 24.6 (0.03-68.6) months and the mean age of the patients was $58.6 \pm 12.3$ years. The mean tumor size was $5.6 \pm 3.3 \mathrm{~cm}$, and when patients were assessed in terms of histologic subtypes, 88 (70.4\%) had clear-cell RCC, 19 (15.2\%) had papillary RCC and 18 (14.4\%) had chromophobe RCC. The mean overall survival was $56.2 \pm 2.4$ months, with 21 patients (16.8\%) exitus during follow-up.
When the patients were initially evaluated in two groups according to clinical metastasis status at the time of diagnosis, it was found that 117 patients did not have metastasis and 8 patients had metastasis and these two groups were compared. Comparative results for the data in both groups are given in Table 2. The mean Fuhrmann nuclear grade was $2.2 \pm 0.6$ in the non-metastasis group and $3 \pm 0.5$ in the metastasis group $(p<0.001)$. NLR was higher in the metastasis group compared

Table 1. Demographic, pathological and laboratory data of patients

\begin{tabular}{|c|c|c|c|}
\hline & & $n=125$ & Percentage $(\%)$ \\
\hline Age (years) (mean $\pm S D)$ & & $58.56 \pm 12.349$ & \\
\hline \multirow[t]{2}{*}{ Sex } & Male & 79 & 63.2 \\
\hline & Female & 46 & 36.8 \\
\hline \multirow[t]{2}{*}{ Site of surgery } & Right & 57 & 45.6 \\
\hline & Left & 68 & 54.4 \\
\hline $\mathrm{NLR}($ mean $\pm \mathrm{SD})$ & & $2.96511 \pm 1.753766$ & \\
\hline Tumor size $(\mathrm{cm})($ mean $\pm \mathrm{SD})$ & & $5.620 \pm 3.2781$ & \\
\hline \multirow[t]{3}{*}{ Pathological subtype of RCC } & CCRCC & 88 & 70.4 \\
\hline & PRCC & 19 & 15.2 \\
\hline & CRCC & 18 & 14.4 \\
\hline \multirow[t]{4}{*}{ Fuhrmann grade } & 1 & 9 & 7.2 \\
\hline & 2 & 85 & 68 \\
\hline & 3 & 26 & 20.8 \\
\hline & 4 & 5 & 4 \\
\hline \multirow[t]{2}{*}{ Microscopic surgical margin status } & Negative & 118 & 94.4 \\
\hline & Positive & 7 & 5.6 \\
\hline \multirow[t]{7}{*}{ Tumor stage according to the TNM classification (Pt) } & T1a & 48 & 38.4 \\
\hline & $\mathrm{T} 1 \mathrm{~b}$ & 33 & 26.4 \\
\hline & T2a & 13 & 10.4 \\
\hline & $\mathrm{T} 2 \mathrm{~b}$ & 7 & 5.6 \\
\hline & T3a & 20 & 16.0 \\
\hline & T3b & 3 & 2.4 \\
\hline & $\mathrm{T} 4$ & 1 & 0.8 \\
\hline \multirow[t]{2}{*}{ Lymph node according to the TNM classification $(\mathrm{N})$} & No & 122 & 97.6 \\
\hline & N1 & 3 & 2.4 \\
\hline \multirow[t]{2}{*}{ Metastasis according to the TNM classification (M) } & Mo & 117 & 93.6 \\
\hline & M1 & 8 & 6.4 \\
\hline \multirow[t]{4}{*}{ TNM stage } & 1 & 81 & 64.8 \\
\hline & 2 & 19 & 15.2 \\
\hline & 3 & 24 & 19.2 \\
\hline & 4 & 1 & 0.8 \\
\hline \multirow[t]{2}{*}{ Overall survival } & Alive & 117 & 83.2 \\
\hline & Deceased & 8 & 16.8 \\
\hline Duration of follow-up (months), median (min-max) & - & $24.6(0.03-68,6)$ & - \\
\hline Overall survival (months) (mean $\pm \mathrm{SD}$ ) & - & $56.2 \pm 2.4$ & - \\
\hline
\end{tabular}


to the non-metastasis group $(4.4 \pm 2.8$ and $2.9 \pm 1.6$, respectively, $\mathrm{p}=0.029$ ). Multivariate analysis also revealed a significant difference in NLR between the groups $(p=0.035)$. Receiver operating characteristics curve analysis identified that the sensitivity and specificity of the NLR cut-off value of 3.1 were $87.5 \%$ and $67.5 \%$, respectively ( $A U C=0.731, p=0.029$ ). When a NLR of 3.1 was taken as a cut-off value, the NLR value in 7 of 8 patients with metastasis at the time of diagnosis was observed to be above 3.1 ( $p=0.002, O R=14.6)$. However, this value did not show a significant correlation with $\mathrm{T}$ stage, Fuhrman nuclear grade, lymph node (LN) involvement, surgical margin positivity, local recurrence and development of metastasis during followup. In the group without metastasis, there were 19 patients with invasive disease (pT3-4) (16\%), while in the metastasis group 6 patients had invasive disease $(75 \%)(p<0.001)$. The number of patients with $\mathrm{LN}$ metastasis was 1 in the non-metastasis group $(0.8 \%)$ and 2 in the clinical metastasis group $(25 \%)(p=0.01)$. The number of patients with positive surgical margins in the nonmetastasis and metastasis groups were $4(3.4 \%)$ and $3(37.5 \%)$, respectively $(p<0.001)$. The mean survival duration in the nonmetastasis group was longer compared to that in the metastasis group $(58.4 \pm 2.3$ months and $18.5 \pm 4.5$ months, respectively, $p<0.001)$. During follow-up, 16 patients in the non-metastasis group (13.6\%) and 5 patients in the metastasis group (62.5\%) were exitus $(p<0.001)$. There were no significant differences for other statistical data.

According to pathological stage, there were 100 patients with pT1-2 and 25 patients with pT3-4. Comparative results for data in the two groups are given in Table 3. Fuhrmann nuclear grade was lower in the pT1-2 group compared to the pT3-4 group

Table 2. Comparison of demographic, pathological and laboratory data of metastatic and non-metastatic patients at the time of diagnosis

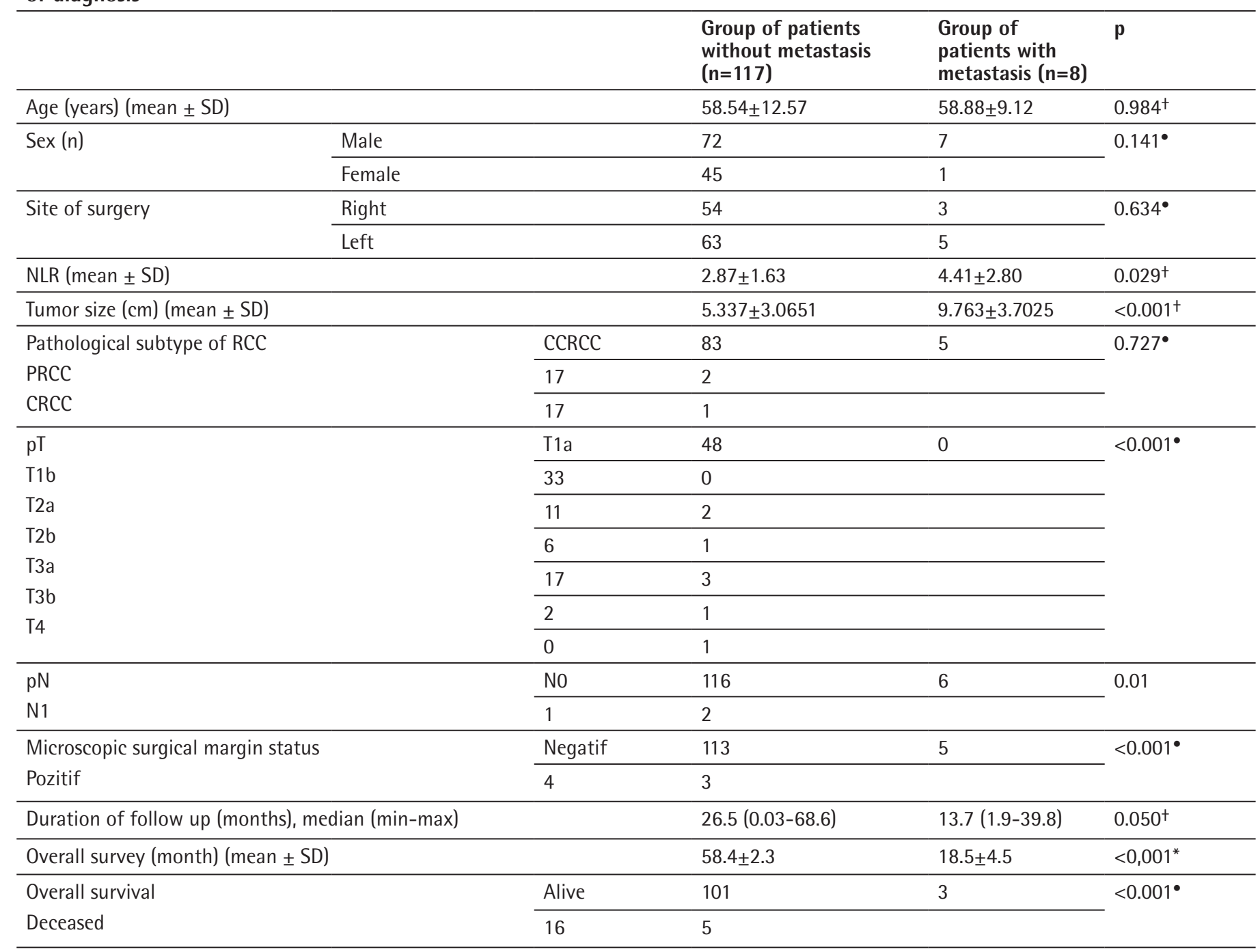

${ }^{\dagger}$ Mann-Whitney U test, ${ }^{\bullet}$ chi-square test, ${ }^{*}$ Kaplan-Meier survival analysis

NLR: Neutrophil/lymphocyte ratio, CCRCC: Clear cell renal cell carcinoma, PRCC: Papillary renal cell carcinoma, CRCC; Chromophobe renal cell carcinoma, SD: Standart deviation, RCC: Renal cell carcinoma 
$(2.1 \pm 0.5$ and $2.7 \pm 0.8$, respectively, $p<0.001)$. The mean tumor size was $5.2 \pm 3.1 \mathrm{~cm}$ in the pT1-2 group and $7.5 \pm 3.2 \mathrm{~cm}$ in the pT3-4 group $(p<0.001)$. NLR was higher in the pT3-4 group compared to the $\mathrm{pT} 1-2$ group ( $3.8 \pm 2.6$ and $2.8 \pm 1.4$, respectively) and multivariate analysis also showed a significant difference in NLR between the groups $(p=0.035)$. While $L N$ metastasis was not observed in patients in the pT1-2 group LN metastasis was present in 3 patients (13.6\%) in the pT3-4 group. The number of patients with clinical metastasis on preoperative assessment was $2(2 \%)$ and $6(24 \%)$ in the pT1-2 and pT3-4 groups, respectively $(p<0.001)$. The number of patients with positive surgical margins was $3(3 \%)$ in the pT1-2 group and $4(25 \%)$ in the pT3-4 group ( $p=0.011)$. On follow-up, the time to recurrence was longer in the pT1-2 group compared to that in the pT3-4 group (63.4 \pm 1.9 months and $28.7 \pm 3.1$ months, respectively, $p<0.001$ ). The mean overall survival was longer in the pT1-2 group than in the pT34 group $(62.8 \pm 1.9$ months and $26 \pm 3.1$ months, respectively; $\mathrm{p}<0.001$ ). During follow-up, 8 patients in the pT1-2 group $(8 \%)$ and 13 patients in the $\mathrm{pT} 3-4$ group $(54.1 \%)$ were exitus $(p<0.001)$. There were no significant differences identified for other statistical data. According to the NLR cut-off value of 3.1, the patients were divided into two groups as NLR $<3.1$ and $>3.1$. There was no significant difference observed in recurrence-free survival between the two groups (Figure 1, NLR $<3.1-60.8 \pm 2.6$ months, NLR $>3.1-56.5 \pm 3.9$ months, $p=0.409$ ). However, when

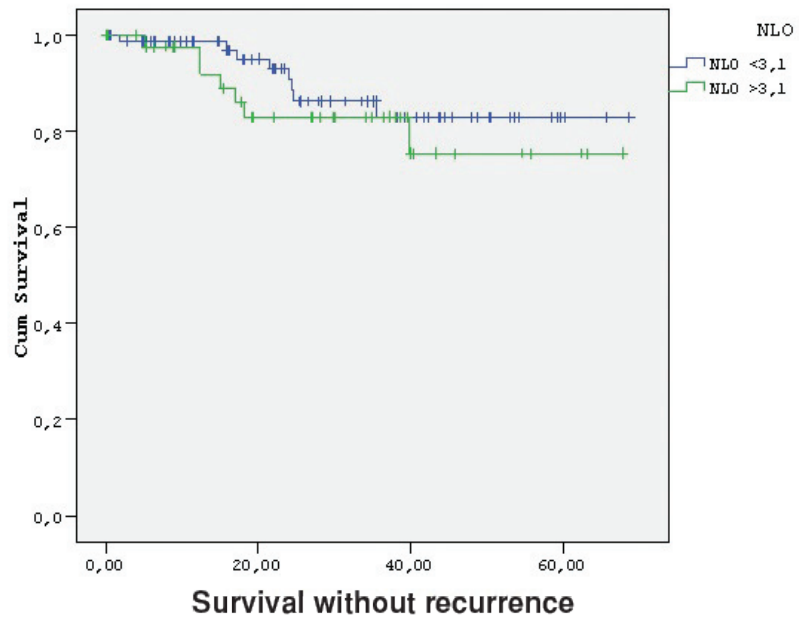

Figure 1. Kaplan-Meier survival plot for relapse-free survival and analysis result

Table 3. Comparison of demographic, pathological and laboratory data of pT1-2 and pT3-4 patients

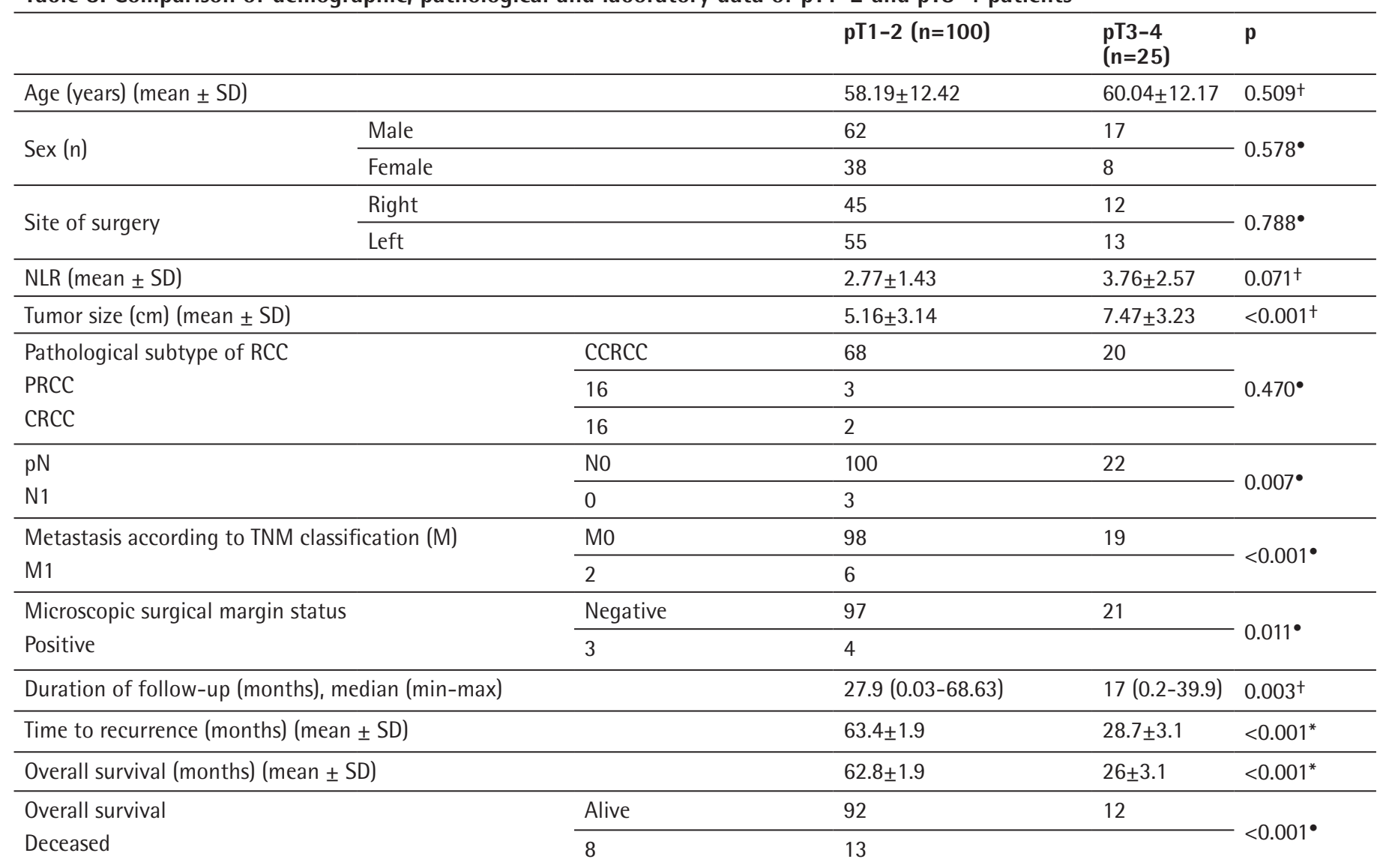

${ }^{\dagger}$ Mann-Whitney U test, $\bullet$ chi-square test, ${ }^{*}$ Kaplan-Meier survival analysis

NLR: Neutrophil/lymphocyte ratio, CCRCC: Clear cell renal cell carcinoma, PRCC: Papillary renal cell carcinoma, CRCC; Chromophobe renal cell carcinoma, SD: Standart deviation,

RCC: Renal cell carcinoma, TNM: Tumor, node, metastases 


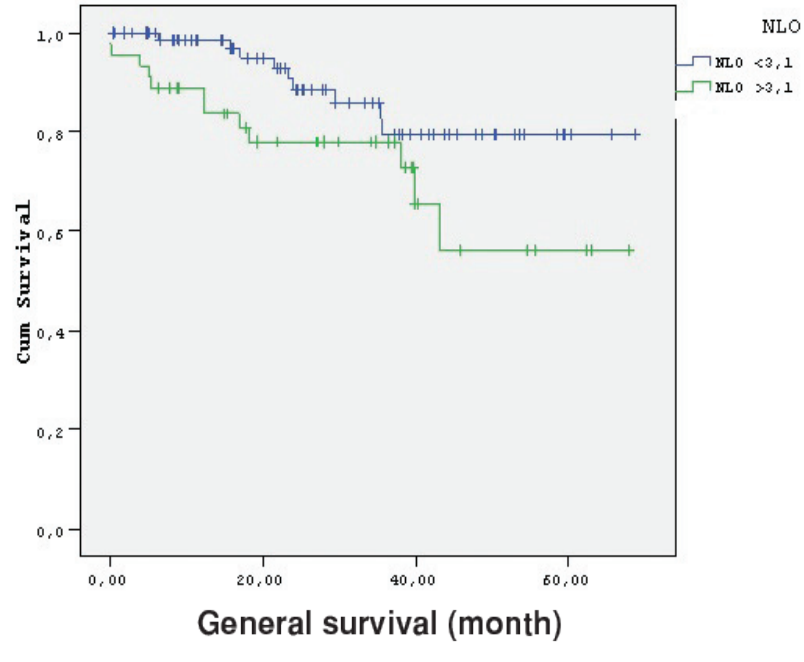

Figure 2. Kaplan-Meier survival plot for OS and analysis result

overall survival was assessed, this value was $59.8 \pm 2.7$ months for patients with a NLR $<3.1$ and $49 \pm 4.5$ months for patients with a NLR $>3.1$ (Figure 2, $p=0.045$ ).

\section{Discussion}

In recent years, many laboratory markers and risk scores associated with these markers have been defined to predict prognosis for RCC patients. Of these, the Leibovich prognosis score, the Mayo clinic stage, size, grade and necrosis score, and ULCA integrated staging system to assess metastasis-free survival and additional immunohistochemical evaluation of biological markers and genomic assessments for RCC follow-up in the postoperative period to assess cancer-free survival are recommended to predict prognosis $(13,14,15,16)$. As a result, we assessed preoperative and postoperative data forming the basis of scoring in our study. In line with this, when we examined our results, NLR in the group with metastasis at the time of diagnosis was identified to be significantly higher compared to that in the group without metastasis. When the patients were grouped according to pathologic stage, NLR was significantly higher in the pT3-4 group than in the pT1-2 group.

Inflammation in the microenvironment of the tumor plays an important role in angiogenesis, proliferation and tumor invasion. Additionally, the intrinsic effect of inflammation is required to inactivate tumor suppressor genes and for oncogene activation (8). High percentage of neutrophil values is associated with chemokines, growth factors and proteases associated with angiogenesis. These neutrophil-associated factors help tumor cells to invade extracellular matrix and vascular wall and development of metastasis (17). Low lymphocyte values are a marker of reduced cellular immune response. Cytokine release preventing tumor distribution and development and cytotoxic cell death occurs due to lymphocytes (18).

The prognostic value of NLR in predicting recurrence was first investigated by Ohno et al. (19) in a study including 192 patients with non-metastatic RCC. This study revealed that patients with a NLR $>2.7$ had worse recurrence-free survival. A study by Tanaka et al. (20) in 2014 found that a high NLR value ( $>3$ threshold value) was associated with advanced T stage, lymphovascular invasion, LN involvement and poor cancerspecific survival. Similarly, in a review of 15 studies, Boissier et al. (21) observed that a NLR $<3$ predicted reduced recurrence risk, with better overall survival and disease-free survival in patients with localized RCC than in those with metastatic and locally advanced RCC. In our study, NLR was higher in the group with metastasis at the time of diagnosis compared to the group without metastasis. In multivariate analysis, NLR was found to be an independent factor for metastasis. When a NLR of 3.1 was accepted as a cutoff value, there was no significant difference in recurrence-free survival, but overall survival was longer in patients with a NLR $<3.1$.

\section{Study Limitations}

Limitations of the study include the retrospective nature of the study and the low number of patients (especially in the metastasis group).

\section{Conclusion}

This study shows that preoperative NLR may be considered a prognostic factor in terms of general survival in RCC patients.

\section{Ethics}

Ethics Committee Approval: Retrospective study.

Informed Consent: Retrospective study.

Peer-review: Externally peer-reviewed.

\section{Authorship Contributions}

Concept: S.Ç., I.B., T.D., S.Y., Design: I.B., Data Collection and/ or Processing: I.H.B., S.Ç., I.B., E.Ş., S.Y., E.A., Analysis and/or Interpretation: S.Ç., I.B., E.Ş., E.A., Literature Research: S.Ç., I.B., T.D., S.Y., Writing: I.B.

Conflict of Interest: No conflict of interest was declared by the authors.

Financial Disclosure: The authors declared that this study received no financial support.

\section{References}

1. Ljungberg B, Albiges L, Bensalah K, Bex A, Giles RH, Hora M, Kuczyk MA, Lam T, Marconi L. European Association of Urology Guidelines on renal cell carcinoma 2017. 
2. Jayson $M$, Sanders $H$. Increased incidence of serendipitously discovered renal cell carcinoma. Urology 1998;51:203-205.

3. Luciani LG, Cestari $R$, Tallarigo $C$. Incidental renal cell carcinoma-age and stage characterization and clinical implications: study of 1092 patients (1982-1997). Urology 2000;56:58-62.

4. Eggener SE, Yossepowitch O, Pettus JA, Snyder ME, Motzer RJ, Russo P. Renal cell carcinoma recurrence after nephrectomy for localized disease: predicting survival from time of recurrence. J Clin Oncol 2006;24:31013106.

5. Edge SB, Compton CC. The American Joint Committee on Cancer: the 7th edition ofthe AJCC cancer staging manual and the future of TNM. Ann Surg Oncol 2010;17:1471-1474.

6. Fuhrman SA, Lasky LC, Limas C. Prognostic significance of morphologic parameters in renal cell carcinoma. Am J Surg Pathol 1982;6:655-663.

7. Volpe A, Patard JJ. Prognostic factors in renal cell carcinoma. World J Urol 2010;28:319-327.

8. Mantovani A, Allavena P, Sica A, Balkwill F. Cancer-related inflammation. Nature 2008;454:436-444.

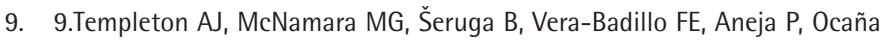
A, Leibowitz-Amit R, Sonpavde G, Knox JJ, Tran B, Tannock IF, Amir E. Prognostic role of neutrophil-to-lymphocyte ratio in solid tumors: a systematic review and meta-analysis. J Natl Cancer Inst 2014;106:124.

10. Wittekind C. 2010 TNM system: on the 7th edition of TNM classification of malignant tumors. Pathologe 2010;31:331-332.

11. Fuhrman SA, Lasky LC, Limas C. Prognostic significance of morphologic parameters in renal cell carcinoma. Am J Surg Pathol 1982;6:655-663.

12. Jungberg B, Cowan NC, HanburyDC, Hora M, Kuczyk MA, Merseburger AS, Patard JJ, Mulders PF, Sinescu IC; European Association of Urology Guideline Group. EAU Guidelines on Renal Cell Carcinoma: the 2010 update. Eur Urol 2010;58:398-406.

13. Cindolo L, Patard JJ, Chiodini P, Schips L, Ficarra V, Tostain J, de La Taille A, Altieri V, Lobel B, Zigeuner RE, Artibani W, Guillé F, Abbou CC, Salzano $L$, Gallo $C$ Comparison of predictive accuracy of four prognostic models for nonmetastatic renal cell carcinoma after nephrectomy: a multi center European study. Cancer 2005;104:1362-1371.

14. Frank I, Blute ML, Cheville JC, Lohse CM, Weaver AL, Zincke H. An outcome prediction model for patients with clear cell renal cell carcinoma treated with radical nephrectomy based on tumor stage, size, grade and necrosis: the SSIGN score. J Urol 2002;168:2395-2400.

15. Zisman A, Pantuck AJ, Dorey F, Said JW, Shvarts O, Quintana D, Gitlitz BJ, deKernion JB, Figlin RA, Belldegrun AS. Improved prognostication of renal cell carcinoma using an integrated staging system. J Clin Oncol 2001;19:1649-1657.

16. Karakiewicz PI, Briganti A, Chun FK, Trinh QD, Perrotte P, Ficarra V, Cindolo $L$, De la Taille A, Tostain J, Mulders PF, Salomon L, Zigeuner R, Prayer-Galetti T, Chautard D, Valeri A, Lechevallier E, Descotes JL, Lang H, Mejean A, Patard JJ. Multi-institutional validation of a new renal cancer specific survival nomogram. J Clin Oncol 2007;25:1316-1322.

17. De Lorco JE, Wuertz BR, Furcht LT. The potential role of neutrophils in promoting the metastatic phenotype of tumors releasing interleukin-8. Clin Cancer Res 2004;10:4895-4900.

18. Ding PR, An X, Zhang RX, Fang YJ, Li LR, Chen G, Wu XJ, Lu ZH, Lin JZ, Kong LH, Wan DS, Pan ZZ. Elevated preoperative neutrophil to lymphocyte ratio predicts risk of recurrence following curative resection for stage IIA colon cancer. Int J Colorectal Dis 2010;25:1427-1433.

19. Ohno $Y$, Nakashima J, Ohori M, Hatano $T$, Tachibana M. Pretreatment neutrophil-to-lymphocyte ratio as an independent predictor of recurrence in patients with nonmetastatic renal cell carcinoma. J Urol 2010;184:873878.

20. Tanaka N, Kikuchi E, Kanao K, Matsumoto K, Shirotake S, Miyazaki $Y$, Kobayashi H, Kaneko G, Hagiwara M, Ide H, Obata J, Hoshino K, Hayakawa N, Kosaka T, Hara S, Oyama M, Momma T, Nakajima Y, Jinzaki M, Oya M. A multi-institutional validation of the prognostic value of the neutrophiltolymphocyte ratio for upper tract urothelial carcinoma treated with radical nephroureterectomy. Ann Surg Oncol 2014;21:4041-4048.

21. Boissier R, Campagna J, Branger N, Karsenty G, Lechevallier E. The prognostic value of the neutrophil-lymphocyte ratio in renal oncology: A review. Urol Oncol 2017;35:135-141. 